\title{
Immunological variability of rice varieties depending on growing conditions
}

\author{
Olesya Bragina*, Andrey Ogly, and Pshimaf Khachmamuk \\ Federal Scientific Rice Centre, Krasnodar, Belozerny, 3350921, Russia
}

\begin{abstract}
Blast (causative agent Pyriculariaoryzae Cavara) plays an important role among economically important, dangerous and harmful rice diseases of rice in all rice-growing countries, including Russia. The problem of resistance of rice plants to disease is one of the main problems in modern breeding in most countries. Intensification of rice cultivation creates a favorable microclimate in the sowing agrocenosis for the development of blast disease and leads to an increase in its harmfulness. The varieties quickly lose their resistance to new races of the pathogen, due to high spontaneous variability of the $M$. grisea fungus, its field populations are usually represented by a mixture of races with different virulence and aggressiveness, outstripping the evolution of the host plant. The nature of the blast manifestation depends on the agroclimatic conditions and genotype. The article presents the results of research at experimental and production plots of Federal Scientific Rice Centre (FSC of Rice) and Elite Seed-Production Experimental Statation Krasnaya (ESPES Krasnaya). It has been shown that a clear differentiation of rice varieties in terms of blast resistance and yielding properties is possible only when certain (provocative) conditions are created that contribute to the manifestation of their genetic potential, while the blast resistance of varieties cannot be provided only by the introduction of one gene of racespecific resistance. A close negative relationship was obtained between the yield and the intensity of blast disease on two backgrounds of mineral nutrition: $\mathrm{N}-1-\mathrm{r}=-0.93$; $\mathrm{N}-2-\mathrm{r}=-0.95$. The determination coefficients showed that in $86.8-90.1 \%$ of cases, the yield is due to the intensity ofblast development on the crops of the studied rice varieties.
\end{abstract}

Blast causative agent - imperfect fungus Pyriculariaozyzae Cavaza (fertile form Magnaporthagrisea Hebert Barr.), parasitizing on young actively vegetating tissues, forming a colorless multicellular mycelium, which spreads through the intercellular glands and plant tissues [1].

Blast is the most dangerous and harmful rice disease, widespread in most rice-growing regions of the world, including Russia. The World Institute of Mycology has registered this disease in more than 80 countries. In recent years, a high severity of this disease has been noted in all rice-growing zones of the world. One of the main reasons contributing to the intensive development of blast is the lack of resistant varieties and the cultivation of genetically homogeneous varieties over large areas [2,3].

\footnotetext{
* Corresponding author: olesya.bragina.1984@mail.ru
} 
Rice varieties released in Krasnodar Territory are mainly characterized as medium resistant. At the same time, depending on the growing conditions, their resistance can vary. Growing resistant varieties increases the profitability of production and reduces the pesticide load on agrocenoses, as well as reduces environmental pollution [4,5]. However, development of resistant varieties is a long and knowledge-intensive process. The difficulty of breeding for resistance to diseases lies in the fact that donors of resistance in one agroecological zone may be severely affected by the pathogen in another, since the intraspecific composition of the population changes depending on external conditions. In addition, along with the resistance of varieties, chemical and biological protection of rice from the disease, the technology of growing crops, especially varietal agricultural technology, has a great influence on the intensity of disease development [6-10].

The main purpose of the study is to identify the immunological variability of rice varieties to Pyriculariaoryzae Cav. depending on morphophysiologicaltraits and growing conditions. To study this issue for two years (2019-2020), field experiments were carried out at the experimental production plot(EPP) of FSBSI FSC of Rice (Krasnodar) for the predecessor winter wheat and at the FSBI ESPES "Krasnaya" (Krasnoarmeysky District) for the predecessor alfalfa for 2 years. Released rice varieties of various morphotypes served as a material of the study: Rapan (st), Nautilus (genes for race-specific resistance Pib + Pi-z), Partner (Pi-b), Vizit, Kazachok-4, Favorit. The varieties were sown with a selection seeder of the batch type, plots with an area of $10 \mathrm{~m}^{2}$ with three seeding rates $(5,7$ and 9 million germinating seeds/ha), against the background of mineral nutrition adopted by the farm, in four replications. During the rice growing season, phenological observations were carried out (fixing the dates of the main growing phases), counting the density of seedlings. An assessment of plants resistance to damage by the blast pathogen on a natural infectious background in the phases of emergence-flowering and grain filling was carried out. The resistance of plants to disease was determined by visual inspection of the whole plant by damage to leaves, nodes, stems and panicles and two indicators: the type of reaction (in points) and the intensity of damage to plants in\%, according to a ten-point scale of the International Rice Research Institute [11].

On average, over two years of research, in environmental testing experiments, the response of rice varieties to blast resistance was ambiguous (Figure 1).

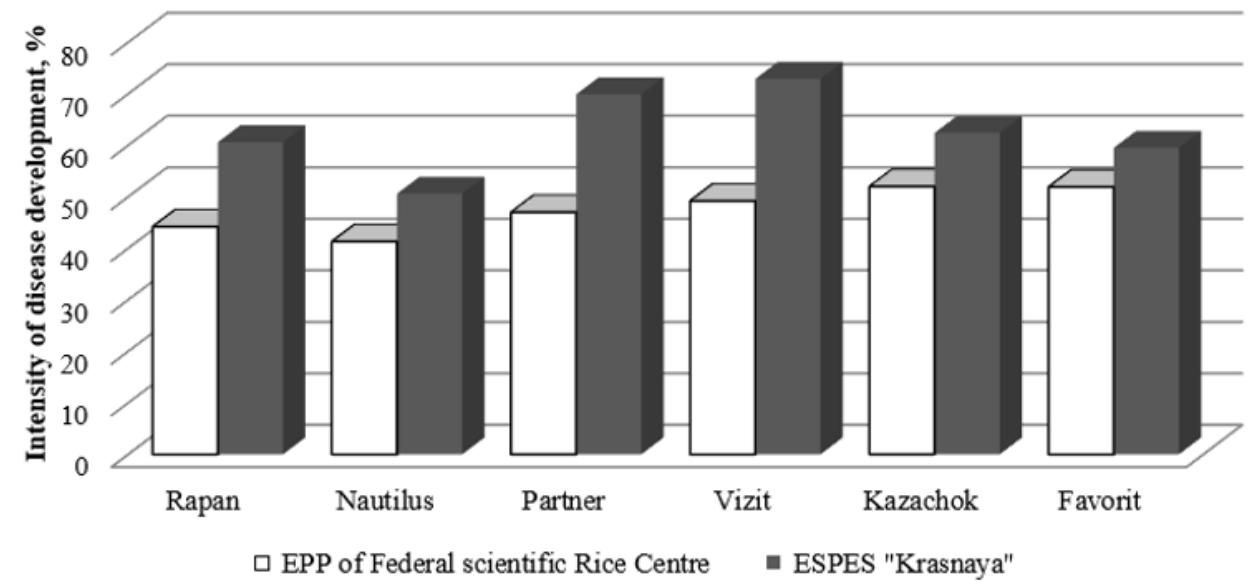

Fig. 1. Intensity of blast development on rice varieties in different agroecological conditions(20192020)

Most of them showed themselves as moderately resistant (Rapan, Nautilus, Partner, Vizit) under the conditions of Federal Scientific Rice Centre EPP- the intensity of disease 
development (IDD) varied from 41.3 to $49.2 \%$. The varieties Kazachok-4 and Favorit were affected more (IDD - 51.9 -52.0).

In the ESPES "Krasnaya", all genotypes passed into the group of susceptible ones. The intensity of blast development was in the range of 50.6 - 72.9\%, varieties Partner and Vizit were characterized by the greatest susceptibility.

The main criterion for variety value and suitability for use is yield, which depends on the genetic potential of productivity and adaptability to growing conditions. Table 1 shows the results of studying rice varieties at different seeding rates in ESPES "Krasnaya", Krasnoarmeisky district and EPP of Federal Scientific Rice Centre, Krasnodar for 2019.

Table 1. Yield, intensity of blast development, planting density of rice varieties in different agroecological rice growing zone softheregion, 2019

\begin{tabular}{|c|c|c|c|c|c|c|c|}
\hline \multirow{2}{*}{ Variety } & \multirow{2}{*}{$\begin{array}{l}\text { Seeding } \\
\text { rate }\end{array}$} & \multicolumn{3}{|c|}{ ESPES"Krasnaya" } & \multicolumn{3}{|c|}{$\begin{array}{c}\text { EPP of Federal Scientific Rice } \\
\text { Centre }\end{array}$} \\
\hline & & $\begin{array}{l}\text { Yield, } \\
\text { c/ha }\end{array}$ & $\begin{array}{l}\text { IDD, } \\
\%\end{array}$ & $\underset{\mathrm{pcs} / \mathrm{m}^{2}}{\text { Plantingdensity }}$ & $\begin{array}{l}\text { Yield, } \\
\text { c/ha }\end{array}$ & $\begin{array}{l}\text { IDD, } \\
\%\end{array}$ & $\begin{array}{l}\text { Plantingdensity } \\
\text { pcs } / \mathrm{m}^{2}\end{array}$ \\
\hline \multirow{3}{*}{ Rapan (st) } & $5 \mathrm{mln}$. & 69,3 & 57,8 & 265 & 77,8 & 39,5 & 230 \\
\hline & $7 \mathrm{mln}$. & 76,8 & 58,9 & 370 & 81,5 & 42,8 & 323 \\
\hline & $9 \mathrm{mln}$. & 77,9 & 60,0 & 419 & 81,4 & 40,5 & 383 \\
\hline \multirow{3}{*}{ Nautilus } & $5 \mathrm{mln}$. & 88,8 & 46,7 & 276 & 81,0 & 37,1 & 234 \\
\hline & $7 \mathrm{mln}$. & 93,5 & 48,9 & 356 & 84,4 & 40,0 & 280 \\
\hline & $9 \mathrm{mln}$. & 91,8 & 50,1 & 402 & 84,6 & 39,5 & 342 \\
\hline \multirow{3}{*}{ Partner } & $5 \mathrm{mln}$. & 53,0 & 62,7 & 301 & 75,5 & 37,2 & 232 \\
\hline & $7 \mathrm{mln}$. & 51,5 & 64,4 & 389 & 79,2 & 42,2 & 293 \\
\hline & $9 \mathrm{mln}$. & 48,0 & 65,8 & 424 & 74,3 & 48,1 & 367 \\
\hline \multirow{3}{*}{ Vizit } & $5 \mathrm{mln}$. & 41,0 & 65,5 & 243 & 76,2 & 39,4 & 217 \\
\hline & $7 \mathrm{mln}$. & 46,1 & 67,5 & 315 & 84,0 & 41,1 & 284 \\
\hline & $9 \mathrm{mln}$. & 39,6 & 69,4 & 398 & 85,5 & 42,8 & 349 \\
\hline \multirow{3}{*}{ Kazachok-4 } & $5 \mathrm{mln}$. & 61,9 & 57,8 & 332 & 70,1 & 49,2 & 277 \\
\hline & $7 \mathrm{mln}$. & 61,0 & 61,7 & 392 & 79,6 & 50,0 & 302 \\
\hline & $9 \mathrm{mln}$. & 56,2 & 63,3 & 485 & 71,9 & 48,7 & 375 \\
\hline \multirow{4}{*}{ Favorit } & $5 \mathrm{mln}$. & 68,7 & 54,9 & 313 & 78,3 & 40,2 & 222 \\
\hline & $7 \mathrm{mln}$. & 76,9 & 56,0 & 386 & 85,0 & 41,3 & 290 \\
\hline & $9 \mathrm{mln}$. & 76,2 & 57,7 & 492 & 76,7 & 45,3 & 389 \\
\hline & $\begin{array}{l}\text { mean } \\
\text { value }\end{array}$ & 65,5 & 59,4 & 364,2 & 79,1 & 42,6 & 299 \\
\hline \multicolumn{2}{|c|}{$\mathrm{LSD}_{05}$} & 5,5 & & & 3,5 & & \\
\hline
\end{tabular}

In EPP of Federal Scientific Rice Centre the yield of all varieties increases at a seeding rate of 7 million germinating grains/ha, at 9 million in the varieties Partner, Kazachok-4 and Favorit, it decreases, and in Rapan, Nautilus and Vizit it does not change. It should be noted that Kazachok-4 showed the lowest yield for all seeding rates, which is associated with a higher intensity of disease development and suboptimal planting density for varieties of this type.

On average, the yield of rice varieties was 79,1 c/ha, with an intensity of blast development of $42.6 \%$ and a plant density of $299 \mathrm{pcs} / \mathrm{m}^{2}$.

In the conditions of the ESPES "Krasnaya", the infectious background in 2019 was much higher in comparison with FSC of Rice, which negatively affected the yield of most varieties. So, the average yield was $65.5 \mathrm{c}$ /ha with the intensity of disease development $-59.4 \%$. The highest yield for all variants of the experiment was formed by the variety Nautilus, which has the genes of 
race-specific blast resistance $P i-b$ and $P i$-z. The intensity of the disease development in this variety varied from 46,7 to 50,1\%, and the yield was 88,8; 93,5; 91,8 c/ha, according to seeding rates 5, 7, 9 million germinating grains / ha, respectively.

The smallest yield in the experiment was in varieties Partner (with the $P i-b$ resistance gene) and Vizit, which is due to high degree of blast damage to plants. So, the yield of Partner varies within 48,0-53,0 c/ha, IDD- 62,7 - 65,8\%; Vizithas a yield of 39,6 - 46,1 c/ha, IDD- 65,5$69,4 \%$.

Variety Kazachok-4 formed a higher yield than Partner and Vizit, however, significantly inferior to other varieties, with yield varying by seeding rates in the range of 56,2 -61,9 c/ha. It should be noted that Kazachok-4 reduces the yield, with an increase in the seeding rate to 9 million germinating grains per hectare, the IDD of this variety on two backgrounds is 57.8 $63.3 \%$, respectively. Favorit, belonging to the same group of varieties as Kazachok-4, in terms of yield is at the level of the standard variety Rapan (68.7 - 76.9 c / ha), but with a lower IDD (56.0 - 57.7\%).

In ESPES "Krasnaya" in 2020, the intensity of disease development on varieties was higher in comparison with 2019, which negatively affected the yield (Figure 2).

Yield of rice varietes in ESPES "Krasnaya" in 2020

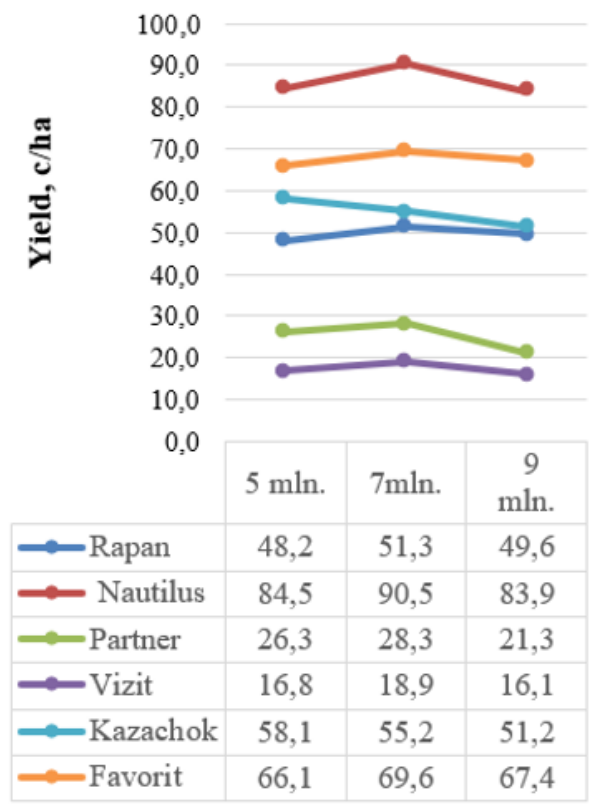

Yield of rice varietes in EPP of Federal scientific rice centre 2020

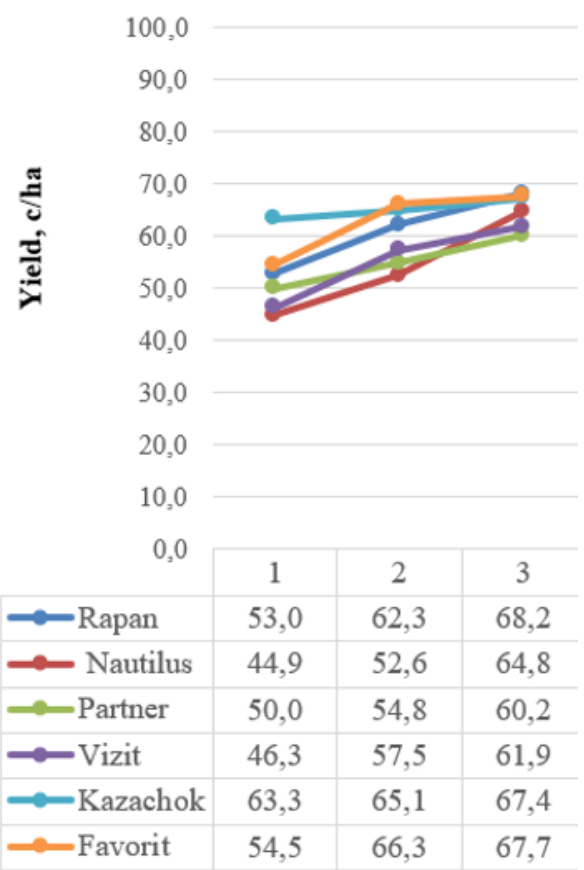

Fig. 2. Yieldofricevarietiesin ESPES "Krasnaya", EPP of Federal scientific Rice Centre, 2020

So the average yield was 50,2 c/ha, Nautilus showed a good yield, its IDD was 56\%, the lowest yield was in Vizit, IDD - 83,7\%; Partner, IDD - 86,5\%.

Under the conditions of ESPES "Krasnaya" varieties make the greatest significant contribution to the yield variation - 86.6\%. The seeding rate has little effect on the yield $0.6 \%$. As a result of the correlation-regression analysis, a close negative relationship between the yield and the intensity of blast development was obtained $-r=-0.93$. The coefficient of determination shows that in 86,8 cases, the yield is due to the intensity of blast disease on the crops of the studied rice varieties. 
The significance of the differences in the variants of the experiment is confirmed by the results of the three-way analysis of variance.

Under the conditions of the ESPES "Krasnaya" varieties make the greatest significant contribution to the yield variation - 86.6\%. The seeding rate has little effect on the yield $0.6 \%$. The proportions of the influence of other sources of variation are small and unreliable, since the actual values of the Fisher criterion are less than the tabular values.

As a result of the correlation and regression analysis (Figure 3), a close negative relationship between the yield and the intensity of blast development was obtained - $r=-$ 0.93. The coefficient of determination shows that in 86,8 cases, the yield is due to the intensity of blast disease on the crops of the studied rice varieties.

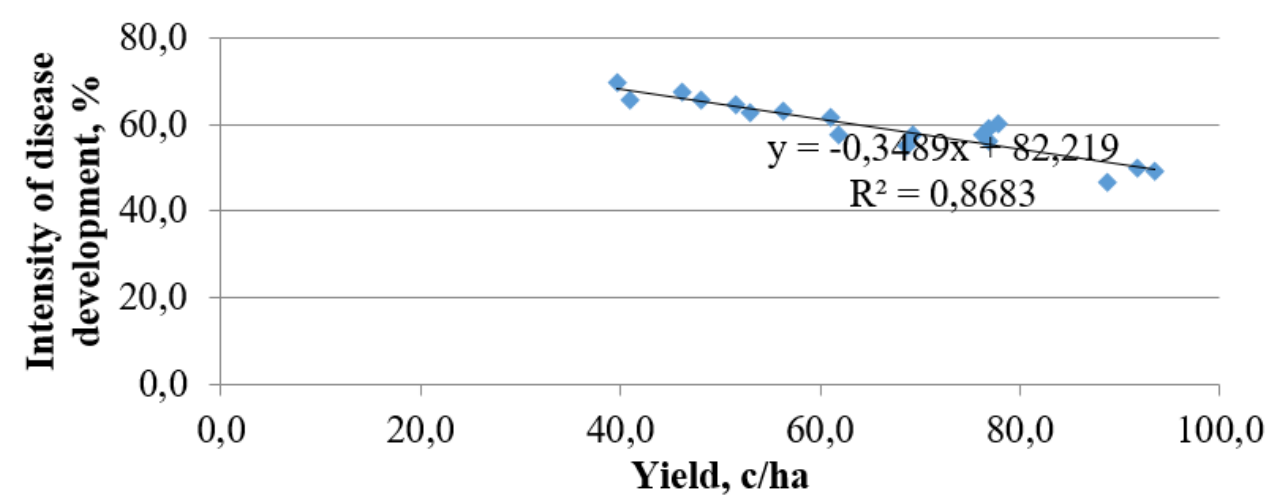

Fig. 3. The relationship between the yield of rice varieties and the intensity of blast development under the conditions of ESPES "Krasnaya"

Under the conditions of EPP of Federal Scientific Rice Centre, the varieties make the greatest significant contribution to the yield variation $-42.8 \%$, the seeding rate $-11.9 \%$. Correlation-regression analysis (Figure 4) established a negative relationship between the yield and the intensity of blast damage to varieties - $r=-0.52$. In accordance with the coefficients of determination, $27,0 \%$ of the yield variability depends on blast resistance of genotypes.

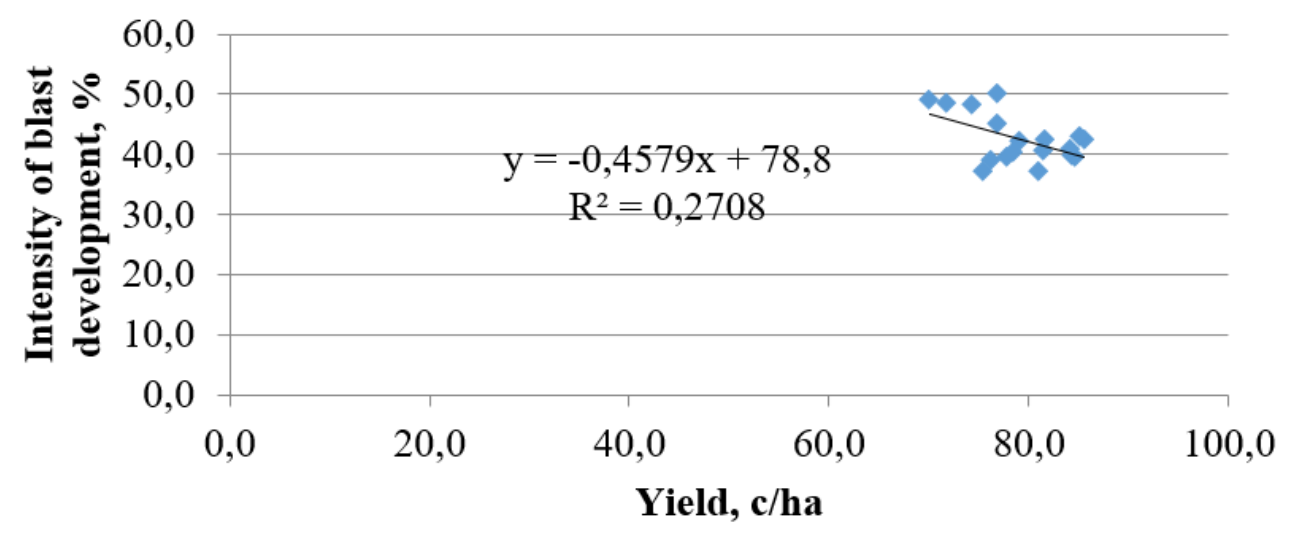

Fig. 4. The relationship between the yield of rice varieties and the intensity of blast development under the conditions of EPP of Federal Scientific Rice Centre 
Comparing the results of studies for two years at EPP of Federal Scientific Rice Centre and at ESPES "Krasnaya", we can conclude that a clear differentiation of rice varieties in terms of their blast resistance and yielding properties is possible only when certain (provocative) conditions are created that contribute to the manifestation of their genetic potential, while the resistance of varieties to blast cannot be provided only by introduction of one gene of race-specific resistance. Any newly developed variety must have horizontal (field) resistance. Only in this case the effect will be obtained from the introduction of genes by the method of back-crossing breeding using DNA technologies. In addition, groups of varieties with a large biomass, such as Kazachok-4, Favorit, suffer more from excessive thickening than others. These varieties at the highest seeding rate (9 million germinating grains / ha) under the conditions of Federal Scientific Rice Centre, where the infectious background was not high, sharply decreased the yield, which is associated with a violation of physiological processes in rice plants.

This work was supported by the Russian Foundation for Basic Research and the Krasnodar region Administration No. 19-416-233009

\section{References}

1. Y. Koide, N. Kobayashi, D. Xu, Y. Fukuta, JARQ 43 (4), 255-280 (2009) http://www.jircas.affrc.go.jp

2. M. Yadav, S. Aravindan, U. Ngangkham, S. Raghu, S. Prabhukarthikeyan, U. Keerthana et al., Genetic dissection by gene specific markers. PLOS ONE 14 (3), (2019) https://doi.org/10.1371/journal.pone.0213566

3. J. Van Der Planck, Plant Resistance to Disease (1972)

4. G.L. Zelensky, Materials of the International Scientific and Practical Conference, BolshiyeVyazemy, (2012)

5. O.A. Bragina, M.A. Ladatko, E.A. Malyuchenko, Rice farming, 4 (41) (2018)

6. E. A.BalliniJ. B. Morel, G. Droc et al, Molecular Plant-Microbe Interactions, 21 (2008)

7. H. Huang, L. Huang,G.Feng, S. Wang, Y. Wang,J. Liu,N. Jiang, W. Yan, L. Xu, P. Sun, Z. Li,S Pan.,X. Liu, et al. European Journal of Plant Pathology, 148 (2017)

8. Ashkani, M.Y. Rafii, H.A. Rahim and M.A. Latif. Mol. Biol. Rep. 40(2013) https://doi.org/10.1007/s11033-012-2331-3

9. X. Wu-ming, L. Li-xin, W. Hui1, G. Tao, L. Yong-zhu, Z. Ji-yong, Z. Xiao-yuan, Y. Qi-yun, C. Zhi-qiang Journal of Integrative Agriculture 15 (10) (2016) https://doi.org/10.1016/S2095-3119(16)61415-6

10. X. Zhang, S. Yang, J. Wang, Y.Jia1, J. Huang, S. Tan1, Y.Zhong, L. Wang, L. Gu1, J. Chen, Q. Pan, J. Bergelson, and D. Tian1,Plant J. 84(1)(2015)https://doi.org/10.1111/tpj.12955

11. International Rice Research Institute (IRRI) (1996) // Standard evaluation system for rice. 4th.ed. IRRI - Manila, Phillipine. - 1996. 